\title{
Cattle Culture of Gorkhas and Dairy Development of Assam
}

\author{
Bishnu Prasad Upadhaya \\ (Rsearch Scholar, Bodoland University, Kokrajhar, Assam, India and Principal, Ghanakanta Baruah College \\ Morigaon, Assam, India.)
}

\begin{abstract}
Commercial Dairy farming in Assam had begun during British period. After establishing a bond with Nepal through signing the Treaty of Segowli in 1816, the British Government encouraged the migration of Gorkhas from Nepal with their families. After the Yandaboo treaty in 1826 the Gorkha army men along with the British reached Burma and the kinsman of the Gorkha soldiers accompanied them were offered to rear buffaloes there as sundry jobs. The Syiems (chiefs) of United Khasi Jayantia Hill, who levy a grazing tax on immigrantsa tax which they cannot levy on their own subjects, had encouraged Gorkha graziers to immigrate in this part of NER. During War II numbers of Gorkha Graziers moved to NER from Burma creating milk pockets in different parts of Assam. Depending on this milk pockets numbers of Dairy Cooperatives came up. The establishments of Town Milk Supply Schemes (TMSS) were the first big push in dairy development scenario in Assam. Particularly the Guahati town Milk Supply Scheme was the paver of dairy development in Assam with number of dairy cooperatives formed in its catchment area where dairy farmers of Gorkha community has played major role.
\end{abstract}

Keywords- Cattle, Cooperative Gorkha,Graziers,Milk

\section{INTRODUCTION}

Cattle farming are known to be the primary and culturally inherited business of the Gorkhas in Assam. Therefore it is obvious that this community contributed a lot in Development of the Dairy sector in the state. Development of any sector in an economy basically depends upon the primary stakeholders. In Assam, the Gorkhas are the primary Dairy farmers, prior to the British regime. If one looks impartially at the first few Town Milk Supply Schemes namely in Guwahati, Jorhat, Tezpur and Dibrugarh; which were made functional before 1980 and the location of the catchment area was identified by the survey conducted at the far end of the Second Five Year Plan for setting up Dairy plants under Town Milk Supply Schemes. It reveals that such plants were stalled where Gorkha settlement was concentrated. During initial stage of nation building after the Independence the area under United Khasi-Jaintia hills were also integral parts of Assam with Shillong as its state capital. So, whatever scheme the government of Assam had taken up for Dairy Development, in this part of the state and the effort and contribution made by the citizens thereto for the development undoubtedly form an integral asset of Dairy Development in Assam. This paper is committed to explore the role of the Gorkhas in Dairy Development of Assam

\section{METHODOLOGY}

For the purpose of enquiring into the contribution of indigenous Gorkhas of Assam in the Dairy Sector of the State, the facts found in published Gazetteer, books, journals, and by means of personal interviews and group discussions associated with not later than the period of second five year plan of independent India. In addition the fact collected from personal discussions made in the last few years with a number of past and present stakeholders also are taken as the source of data. The fact and knowledge collected for the purpose is presented here with simple literary analysis. Because of the limitation of resources the enquiry is conducted only around the catchment area of Guwahati Town Milk Supply Scheme to find out socio economic reasons behind their becoming Dairy farmers.

\section{GORKHAS OF PROVINCIAL ASSAM BECAME DAIRY} FARMER: THE PROCESS BEHIND

'Until the last part of the $19^{\text {th }}$ century in Burma, where milk is not used, and a very fine race of buffaloes exists, especially in Pegu' (Henry Frowde, M.A 1909 pp- 232). After establishing a bond with Nepal through signing the Treaty of Segowli in 1816, 'the British Government encouraged the migration of Gorkhas from Nepal with their families'. (Amina Passah-2003). As such after the Yandaboo treaty in 1826 the Gorkha armymen alongwith the British reached Burma and the kinsman of the Gorkha soldiers accompanied them were offered to rear buffaloes there as sundry jobs. 
'The greater numbers of numerous Gorkha graziers in Assam are Jaisis and Upadhyay Brahmins or Chettris of non-martial classes' (Sinha, 1990, p. 229). 'In the nineteenth and twentieth centuries' religious as well as economic reasons forced the Brahmins and Chhetris to be more dependent on livestock and dairy farming than on other possible income sources. The Upadhyaya Bahuns in particular received gifts of cows in funerary rituals, as the Gorkhas believed that if they gift a cow to a priest the dead person could cross the Baitarani (a river) by holding its tail and reach heaven. The Gurungs and Magars, who belonged to martial category, were mostly recruited in the army, but took up dairy farming in Northeast India after retirement.(Lopita Nath 2006).Therefore among the Gorkhas, the Bahuns outnumber in dairy farming. 'In Nagaland, although the Nagas had been engaged in rearing cattle since early, they did so for meat and not for milk. The Gorkhas were the first to teach them about keeping cattle for milk' (Lopita Nath 2006). 'In Khasi hills the cattle were a sturdy little breed, and were only kept for food and for their manure, the indigenous Khasi leaving all the milk to the calf. Buffaloes are kept in the neighbourhood of Shillong by the Gorkhas herdsmen.' (B.C. Allen, 1906) and they kept those cattle and buffaloes for milk. This is culturally continuing after generations. The provincial government introduced grazing tax and authorized the Syiems (Chiefs) of different Syiemships to collect the revenue in the Khasi hills. Recurrence of foot and mouth disease, of course, was a major problem. There was a sociological problem as well. In hill states, the local tribes do not have a tradition of cattle rearing; and the milk neither was a part of dietary habits nor considered vital as food. Even 'among indigenous people of the Brahmaputra Valley, cattle's rearing were not integral to the farming system and was never given the kind of importance that the villagers of Northern India attach to cattle.'(Rangan Dutta 2011).For this very reason the British encouraged migration of graziers from Nepal to Assam. They came with their cattle to different parts of the North-east and set up 'khutis' or small dairy units around urban areas. Large tracts were notified as "professional grazing reserves" and allotted to Gorkha graziers under the Assam Land Revenue Regulations, 1886 on payment of fees. Amina Passah(2003) in her Article Gorkha's in Meghalaya: Diaspora and Identity writes that the immigration of these graziers is, encouraged by the Syiems (chiefs) who levy a grazing tax on immigrants- a tax which they cannot levy on their own subjects-and the immigration of Gorkha graziers is thus a source of considerable profit to them'. The syiemships of Mylliem, Khyrem and Nongkhlaw entrusted with the power to collect Grazing fees, Housing fees (Dohory Khajna), and cultivation tax since British period and perpetuated even after independence. Captain Woodforde who ran the upper Shillong government cattle farm, introduced cross-breeding of local cows with Holstien Frezian bulls in the mid-1930s which gave birth to a mixed breed of high milk yielding cows whom locals of present Assam define as "Shillong" breed.(Rangan Dutta 2011). The breed was named as Belaaite by the periurban farmers of Shillong and reared this breed since 1960s in stall feed system. But still a majority of the cattle farmers mostly relied on the local breed and depended upon forest grazing. Here it is worth mentioning that a large number of Gorkhas in Burma proceeded to North East India when the Indian National Army led by Subhas Ch. Bose was proceeding towards India during War II. In the process many of them came along with their buffaloes. All these increased the number of buffaloes in Manipur and later spread over in and around the Kaziranga paving the way for the formation of Jorhat TMSS.

\section{A PUSH FORWARD BY ASSAM GOVERNMENT AND FORMATION OF MILK COOPERATIVES:}

The Govt. of Assam introduced the dairy development scheme in the State at the last part of the Second Five Year Plan in 1961. Under the scheme, a survey was conducted on various milk pockets and milk shed areas in the state. The target was to procure pure and fresh milk for distributing among the intending consumers of Guwahati town and later to all the important towns in the State. Under the scheme, many Cooperative Societies of milk producers were formed. The Dairy Development Scheme in the State started functioning in 1963. The primary objective was to supply milk to the consumers on 'no profit no loss' basis and to provide incentive to breeders for increasing production by advancing loans to purchase milch cattle, feed, and equipments and to encourage them for better breeding, feeding and management of cattle. In this process a numbers of primary milk producers cooperative societies were formed in the then United Khasi Jaintia Hill districts. The formation of those societies were mostly encouraged by the great expertise viz Dr. J.M. Bujarbaruah, Pulin Baruah, Nandalal Upadhaya along with local people like Bhimlal Lamsal, Jagannath Bawri(Shillong), Kantu Prasad Rijal alias Dumre Mahajan(Umsaw), Bhanu Bhakta Subedi (Nayabanglow), Homlal Lamsal (Mawhati), Kalkatte alias Bal Bahadur Chhetry(Ralla), Madhusudan Bhandari(Kardem), Dhaneswer Tiwari(Umrun), : U Klemshon Mylliemngap (Ralla) etc. Their efforts fruitioned in the 1970s and formed the following milk cooperatives.

a. Ralla [Mowlyndep] Primary Milk Producers Cooperative Society Ltd.

President: U Klemshon Mylliemngap (Bah Dit)

Secretary: Bal Bahadur Chhetry

b. Musura[Umbir] Primary Milk Producers Cooperative Society Ltd. 
President : Agni Prasad Pokharel.

Secretary: Bed Prasad Pokharel.

c. Barghat [Umroi] Primary Milk Producers Cooperative Society Ltd.

President : Chandralal Poudel.

Secretary: Nandalal Ghimire

d. Lalcharai [Mowlen] Primary Milk Producers Cooperative Society

President : Parbati Giri.

Secretary: Shamser Giri.

e. Umran Primary Milk Producers Cooperative Society Ltd.

President : Nirmal Kumar Mahat.

Secretary: Tulshi Ram Upadhaya (Poudel).

f. Mawsyntai Primary Milk Producers Cooperative Society Ltd.

President : Dilli Raj Gewli(Upadhaya).

Secretary: Bhim Bahadur Oli(Chhetri).

g. Mawhati Milk Producers Cooperative Society Ltd.

President: Govinda Prasad Achrya.

Secretary: Chandra Bahadur Chhetri.

h. Umdaittah Primary Milk Producers Cooperative Society Ltd.

President : Sanman Sing Subbha.

Secretary: Motilal Bhandari.

i. Kardem Primary Milk Producers Cooperative Society Ltd.

President : Madhusudhan Bhandari.

Secretary: Tirthalal Sigdel.

j. Umsning(Nayabangla) Primary Milk Producers Cooperative Society Ltd.

President: Bhanu Bhakta Subedi.

Secretary: Nanda Prasad Upadhaya (Luitel).

k. Munakathari Primary Milk Producers Cooperative Society Ltd.

President: Bala Krishna Poudel.

Secretary: Prem Sagar Baral.

1. Raitong,(Bhai Bhai) Primary Milk Producers Cooperative Society Ltd.

President: Tika Ram Devakota.

Secretary: Madhan Bahadur Chhetri.

The above societies, which were formed during the early 1970s had united to form the Bhoi Area Producers' Cooperative Union Ltd. with Bhimlal Lamsal(Jaissi) as president and Captain Dhan Bahadur Thapa as Secretary. It is evidently seen that 90 percent of the dairy farmers of all the cooperative societies and the Union comprised with the milk men of Gorkha community. Here it is worth mentioning that in the History of Dairy Development in the NER the Bhoi Area Producers' Cooperative Union Ltd. was the first union to be formed democratically having characteristic resemblance to ANAND. In the region after the formation of this district union, the then Government of Assam had established a milk chilling plant at Umsning (Nayabanglow) with a capacity of 10,000 LPD. Before the formation of all the Cooperative societies and the Chilling plant at Nayabanglow the cattle farmers were receiving meager amount of income by selling ghee and cream. Here it is to be noted that with an exception of a few farmers of periurban areas of Shillong city all the farmers of the region reared local breed cows till 1980. During the period the cattle were grazed in the forest paying Grazing, Housing and Cultivation fees to respective syiemships. Some farmers under Kardem and Mawhati area used to keep buffaloes. The maximum herds of buffaloes were found in the adjoining areas of Mikir Hills (Now Karbi anglong) beyond Kardem and Moulasnai in Khasi Hill. In Mikir hills comprising the area of Umlaphir, Mousladiang, Umat, Umponai, Langerdang etc., one Bhai - Bhai Primary milk Producers Cooperative society was formed and supplied milk to TMSS Khanapara after chilling the same at Jagiroad chilling plant. This society also had 90 percent of its members from the Gorkha community, most of them rearing Buffaloes. The following chilling plants had been installed at different parts of the State before 1980 by the government of Assam as mentioned in the Assam State Gazetteer (1999).

\begin{tabular}{|l|l|c|}
\hline Name of the Chilling Plant & Capacity-LPD & Distribution \\
\hline \multicolumn{1}{|c|}{$\mathbf{1}$} & \multicolumn{1}{|c|}{$\mathbf{2}$} & $\mathbf{3}$ \\
\hline Nayabunglow & $\mathbf{1 0 , 0 0 0}$ litres & Guwahati T.M.S. \\
\hline Jagiroad & $\mathbf{6 0 0 0}$ & " \\
\hline Sipajhar & $\mathbf{2 0 0 0}$ & \\
\hline
\end{tabular}




\begin{tabular}{|l|l|c|}
\hline Boko & $\mathbf{1 0 0 0}$ & "“ \\
\hline Bokakhat & $\mathbf{2 0 0 0}$ & JorhatT.M.S. \\
\hline Joysagar & $\mathbf{2 0 0 0}$ & " \\
\hline Biswanath Chariali & $\mathbf{2 5 0 0}$ & Tezpur T.M.S \\
\hline Lakhowal & $\mathbf{2 5 0 0}$ & Dibrugarh \\
\hline
\end{tabular}

One can take a note that Chilling Plants under the government plan were installed near the Gorkhas settlement areas in Jagiroad and Nayabunglow (comprising Umsaw, Umroi, Bhoirymbong, Mawhati etc.) where Dairy farmers of Gorkha community were highly concentrated. 'Informal Milk Producing Units In Guwahati City' the study carried out by J.Saikia (2009) found that Highest percentage of entrepreneurs (96.04\%) are of Gorkha community. Studying about the interstate migration he found that some of the Gorkha entrepreneurs have migrated from the nearby state of Meghalaya during the period 1971-72 and settled down in Assam and run their dairy business in the state. Gorkhas, Migrated from Meghalaya was found to be $41.58 \%$ of population Sample. Further, Report of Advisory Committee on Animal Husbandry \& Dairying (2009) states that there is no state milk federation. There are 3 milk unions in the state out of which Cachar \& Karimganj Milk Union Ltd. (CAMUL) and East Assam Milk Union Ltd. (EAMUL) are non operational while the only Milk union i.e. West Assam Milk Union Ltd. (WAMUL) is in operation.

\section{CONCLUSION:}

The analysis above evidently provides interesting result. The effort made by the then government of Assam has still bearing its fruit although the area has gone under the statehood of Meghalaya. After the formation of Meghalaya, numbers of Dairy farmers shifted permanently to periurban areas of Guwahati in search of a viable socio economic fraternity. Further it is seen that only West Assam Milk Union Ltd. (WAMUL) is in operation among the Milk Union formed in Assam. On the other hand the TMSS Guwahati is also operating till date. Both the institutions are located amid the high density area of Gorkha Dairy farmers. Here it is needless to quote much on Sitajakhala Dugdha Utpadak Samabai Samiti Ltd the only longest running Milk Cooperative in Northeast India which was established, developed and run by the people of Gorkha community and is the primary feeder cooperative society of TMSS Guwahati and WAMUL since their inception. This study concludes that the domiciled Gorkhas as well as keeping own culture intact have played positive role by implementing dairy schemes to fulfill the dream of the then AH \& Veterinary crusader Dr. J. M. Bujarbaruah. At last we wish that more liberal and practical policies of the government in future would accelerate the progress of the community and dairy sector in the state as well.

\section{ACKNOWLEDGEMENTS:}

I am grateful to C M Adhikari (Nayabanglow), Krishna Prasad Rijal (Dumre) Son of Late Kantu Prasad Dumre (Umsning), Keshab Koirala (Habang), Dilu Subedi (Umroi), Ganesh Gewali(Jagiroad) Chudamani Sharma(Dudhnai), Nandalal Upadhaya(Jagiroad) and Indra Prasad Upadhaya(Amlighat ) who helped with their practical Knowledge.

\section{REFERENCES:}

[1] Amena Passah (2003): Gorkha's in Meghalaya: Diaspora and Identity; in Sinha, A.C. and Subba, T.B. (eds) The Gorkhas in North-east India: a community in search of Indian identity (New Delhi, Indus)

[2] Assam State Gazetteer (1999): Vol.-I, The editor-in-Chief, District Gazetteers; Government of Assam, Guwahati.

[3] B. C. Allen (1906): Assam District Gazetteers.Volume X. The Khasi And Jaintia Hills, The Garo Hills And The Lushai Hills) Pp 81

[4] Jugal Saikia(2009): Economics of Informal Milk Producing Units in Guwahati City; a thesis submitted for the award of Doctor of Philosophy in economics of North Eastern Hill University Shilllong, Meghalaya.

[5] Lopita Nath(2006): Migration, Insecurity and Identity: The Gorkha Dairymen in India's Northeast; Asian Ethnicity, Volume 7, Number 2, June 2006

[6] Rangan Dutta(2011): Now need for a white revolution 8 August 2011 Statesman Kolkata.

[7] Report of Advisory Committee on Animal Husbandry \& Dairying(2009): Volume II [ State Specific Reports]; Planning Commission, Government of India, Yojana Bhavan, New Delhi December, 2009 chapter 3 4.0 Dairy Sector

[8] Volume II [ State Specific Reports]; Planning Commission, Government of India, Yojana Bhavan, New Delhi December, 2009 chapter 3 4.0 Dairy Sector. 